\title{
EVALUATION OF THE SURFACE EROSION FROM DIFFERENT TIMBER YARDING METHODS IN HONDURAS ${ }^{1}$
}

\author{
Samuel Rivera ${ }^{2}$, Jeffrey L. Kershner ${ }^{3}$ and James P. Dobrowolski ${ }^{4}$
}

\begin{abstract}
Surface runoff and sediment production from different timber yarding practices, some using Best Management Practices (BMPs) recommended for Honduras, were monitored in experimental plots during the rainy seasons of two consecutive years in pine forest highlands of central Honduras. Different timber yarding systems were applied to pseudo-replicated plots during the rainy seasons of 1999 and 2000. In 1999, two treatments were studied: tractor yarding and skyline cable (a recommended BMP). In 2000, four treatments were evaluated: tractor skidding, skyline cable, animal skidding (another recommended BMP), and undisturbed forest (reference). During the rainy seasons of these years, surface runoff volumes and sediment yield were measured at five $1.5 \mathrm{~m} \times 10 \mathrm{~m}$ erosion plots in each treated area. The results showed significant differences between traditional tractor yarding and the recommended skyline cable and animal skidding methods. Tractor yarding produced six to ten times more erosion during the rainy seasons than cable and animal yarding. The improved soil retention of cable and animal yarding was especially important during September when the highest rainfall occurred in this climate.
\end{abstract}

Keywords: BMP, Erosion and Timber yarding evaluation.

\section{AVALIAÇÃO DA EROSÃO SUPERFICIAL DE DIFERENTES MÉTODOS DO CARREGAMENTO DA MADEIRA EM HONDURAS}

\begin{abstract}
Resumo - A produção do escorrimento de superfície e do sedimento das práticas diferentes do carregamento da madeira, algumas das melhores práticas de gestão de utilização (BMPs) recomendadas para Honduras, foi monitorada em lotes experimentais durante as estações das chuvas de dois anos consecutivos em montanhas da Floresta do Pinho de Honduras. Os diferentes sistemas do carregamento da madeira foram aplicados aos lotes pseudorreplicados durante as estações das chuvas de 1999 e de 2000. Em 1999, dois tratamentos foram estudados: cabo do carregamento e do trator (um BMP recomendado). Em 2000, quatro tratamentos foram avaliados: sistemas do carregamento da madeira do trator, cabo, animal e floresta imperturbada (referência). Durante as estações das chuvas desses anos, os volumes do escorrimento de superfície e o rendimento do sedimento foram medidos em cinco lotes da erosão de $1,5 \mathrm{~m}$ x $10 \mathrm{~m}$ em cada área tratada. Os resultados indicaram diferenças significativas entre o carregamento tradicional do trator e o do cabo e do animal. O carregamento do trator produziu 6 a 10 vezes mais erosão durante as estações das chuvas do que o carregamento do cabo e do animal. A retenção melhorada do solo do carregamento do cabo e do animal foi especialmente importante durante o mês de setembro, quando ocorreu a precipitação mais elevada.
\end{abstract}

Palavras-chave: Erosão, Métodos do carregamento da madeira e Avaliação.

\section{INTRODUCTION}

Erosion from timber yarding can result in water quality impairment, aquatic habitat degradation, lowered soil productivity and infrastructure damage. In the United States, various federal and state agencies have developed practices to control non-point source pollution from forestry operations and by 1982 most states had implemented practices to control non-point source pollution from forestry practices (Ice et al. 2004). In tropical scenarios, erosion problems have an enormous impact on soil loss of fertility and water quality in streams and rivers (Ribeiro et al. 2007).

\footnotetext{
${ }^{1}$ Recebido em 06.11.2008 e aceito para publicação em 02.03.2010.

${ }^{2}$ Department of Wildland Resources, College of Natural Resources,Utah State University, USA. E-mail: <samuel.rivera@aggiemail.usu.edu> .

${ }^{3}$ Fish and Aquatic Ecology Unit,USDA Forest Service, Watershed Science Department, Utah State University, USA.

${ }^{4}$ Outreach and Education State of Washington, Water Research Center, Washington State University, Department of Natural Resource Sciences.
} 
Best Management Practices (BMPs) are techniques developed to prevent or reduce water pollution from non-point sources by protecting specific critical areas and controlling practices that produce sediments (US Forest Service 2006). BMPs are to be determined by the management agency in charge of a designated area or activity and must be reviewed and approved by the state agency responsible for water quality protection (Clayton 2002). BMPs should be effective, practical, economically and technically feasible, and compatible with current environmental laws and institutional regulations (US Forest Service 1993, 2006; US EPA-US Forest Service 1980). Some BMPs consist of administrative and legal procedures while others are a set of technical procedures. BMPs are designed to reduce non-point source pollution by mediating the relationship between human land use and natural processes (Clayton 2002; US Forest Service 2006; Lynch and Corbett 2007).

In some countries, government agencies have developed a number of Best Management Practices that are implemented during forest operations and are designed to control pollution-causing activities from forest operations (Clayton 2002, US Forest Service 2006). Common forestry BMPs include: no harvest zones adjacent to streams and lakes, water diversion structures on roads and trails, revegetation of disturbed areas, and the use of logging systems that minimize ground disturbance on steep slopes with highly erodible soils (US Forest Service 2006; Lynch and Corbett 2007).

The most common forestry BMPs used to reduce the actual input of sediments into streams include: buffer strips along stream channels, installation of water bars on skid trails, revegetation of disturbed areas (fills and cuts), filter windrows on fill slopes, adequate surface and subsurface drainage structures, proper logging systems, management of harvesting residues, and proper location and design of all haul roads, landings, and skid trails, etc. (Lynch and Corbett 2007; US Forest Service 2006). A number of studies have shown that BMPs have been highly effective in controlling nonpoint source pollution and reducing pollutant output at the watershed scale (Clausen and Meals 1989; Moore et al. 1992; Lynch and Corbett 2007; Ketcheson and Megahan 1996; US Forest Service 2006; Oliveira et al. 2005, Arcova et al. 2003).

The purpose of this study was to compare soil losses from treated and untreated sites during forest harvest. The treatments included timber harvesting using skyline cable (BMPs), tractors (traditional harvesting), animal logging (oxen, BMPs), and undisturbed forest (control, no-harvesting). Runoff volume, infiltration rate, and runoff sediment content were also evaluated at each erosion plot. The hypothesis tested in these experiments was: sediment yield and runoff volume from the treated (BMP logging methods) plots are equal to the non-treated plots (traditional logging methods).

\section{MATERIALS AND METHODS}

\subsection{Study Area}

Honduras is located in the center of the Central American isthmus, between $13^{\circ}$ and $16^{\circ}$ latitude North and $83^{\circ}$ and $89.5^{\circ}$ longitude West (Figure 1 ). It has an area of 112,088 square kilometers. It is a rich country in terms of natural resources and has the highest percentage of forest lands among the other Central American nations (COHDEFOR 2005). Honduras has two types of forest; pine forest located in the central, southern and western parts of the country, and tropical (broadleaf) forest located mainly in the northern and eastern part of the country. Forests cover about $50 \%$ of the country's territory and are divided into broadleaf forests occupying 27,458 square kilometers, and pine forest occupying 27,477 square kilometers. Roughly 57,000 square kilometers are covered by other land uses including: agriculture, grasslands, etc. (Rivera, 2009).

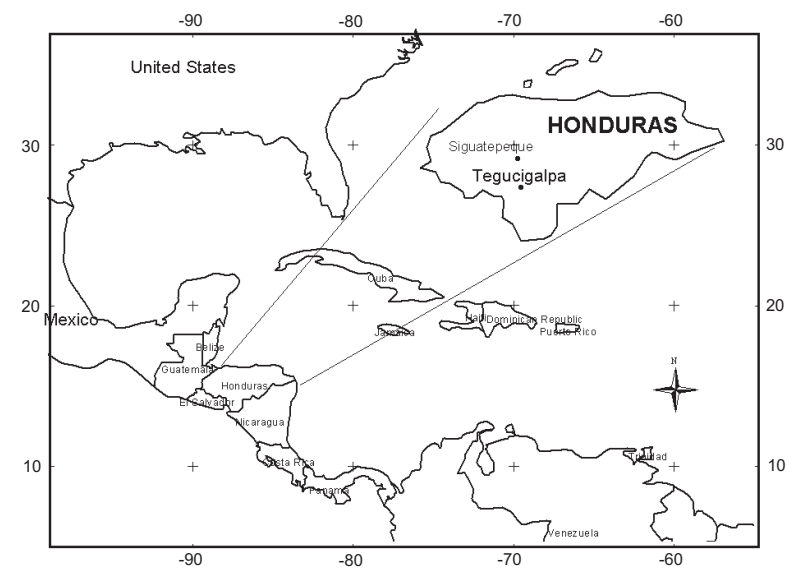

Figure 1 - Location of study site in Siguatepeque, Honduras, Central America.

Figura 1 - Posição do local do estudo em Siguatepeque, Honduras, América Central. 
This study was conducted in the experimental pine forests of the National School of Forest Sciences (ESNACIFOR), located $3.5 \mathrm{~km}$ to the southwest of the town of Siguatepeque, Honduras (Figure 1). The area is mountainous with elevations ranging from 800 to $1,500 \mathrm{~m}$ above sea level. The forest is predominately Pinus oocarpa, with understory of several forbs and grasses. Currently, a forest management plan approved by the forestry government agency indicates that these pine areas can reach densities up to 400 mature trees/ hectare in a rotation period of 35 years (COHDEFOR 2005). Typically, due to the high photosynthetic activity, a pine tree can reach from 30 to $40 \mathrm{~cm}$ diameter and 20 -m height in a period of 20 years.

Terrain is steeply dissected, with residual soils on upland areas and associated colluvium in valley bottoms. Soils are weathered from volcanic rock (basalt and andesite flows) in the some portions of the study area and from sedimentary formations (redbeds and calcareous shales) in the rest of the area. These soil formations are associated with steep terrain and 75\% of the forest lands have slopes greater than $30 \%$. Soils are formed from metamorphic, volcanic, and sedimentary parent materials and have a high to very high erosion risk. The soils are well-drained Lithosols of the series Cocona with a sandy loam texture, and a $\mathrm{pH}$ ranging from 5.0 to 6.0 (Simmons and Castellanos 1969). Actual erosion rates in undisturbed pine forests of Honduras (using runoff plots) have been measured at approximately $40 \mathrm{~kg} / \mathrm{ha} / \mathrm{yr}$ (Hudson et al. 1983).

\subsection{Methods}

A manual of forestry BMP, adapted from Western US, was developed to be used in Honduras (Rivera, 2009). This study is part of operational tests that were conducted to prove the effectiveness of these proposed practices. Specifically, the purpose of this study was to compare soil losses and runoff volumes from different forest harvest methods. The methods - treatmentsincluded timber yarding using skyline cable (BMPs), tractors (traditional yarding), animal yarding (oxen, BMPs), and undisturbed forest (control, no-yarding). Runoff volume, infiltration rate, and runoff sediment content were also evaluated at each erosion plot. The hypothesis tested in these experiments was: sediment yield and runoff volume from the treated (BMP yarding methods) plots are equal to the non-treated plots (traditional yarding methods).
Both control and timber harvest treatments were located in each two first-order watersheds of the ESNACIFOR's school forest (Figure 2). The first watershed was harvested during January of 1999 and the other in January of 2000 year. The yarding method used was the seed tree harvest, which is also a regeneration method, in which mature trees are extracted and middle-aged trees are left standing to provide seed for a new tree generation. After harvesting, the runoff plots were set up and erosion measurements commenced during the following two rainy seasons (June through September/1999 and August through October/2000, respectively). The treatments for the first watershed in 1999 were: cable yarding, and tractor yarding. Treatments for the second watershed in 2000 were: cable yarding, tractor yarding, animal yarding (oxen), and undisturbed forest (control). In both watersheds, five runoff plots were located within each treatment area. Harvesting was conducted during the dry season on both areas and equipment operators were not told about the experiments.

The runoff plots (pseudo-replicates) were established randomly at the approximate center of each treatment or harvest unit. These $10 \mathrm{~m}$ x $1.5 \mathrm{~m}$-runoff plots were aligned with the slope of the unit. Plots were delineated by driving strips of thin-gauge sheet metal (25 cm width) into the ground $(7 \mathrm{~cm})$ and a metal collector was dug into the lower end(McClurkin et al. 1987; Figueroa et al. 1983; Wischmeier and Smith, 1978). Dimensions of the metal collector were determined by calculating the maximum runoff volume for a storm recurrence interval of 5 years.

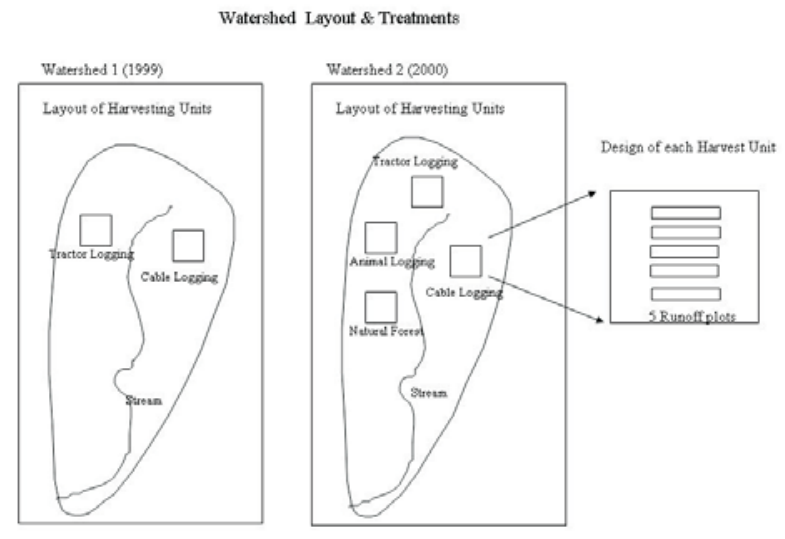

Figure 2 - Layout of the timber yarding experiments. Figura 2 - Disposição das experiências do carregamento da madeira.

Revista Árvore, Viçosa-MG, v.34, n.4, p.577-586, 2010 
All treated areas were harvested and all runoff plots were set up in a range of 30 to $45 \%$ slope. The experimental treatments included:

Tractor yarding - at the felling site, manually felled trees were dragged using the crawled tractor winch through a skid trail (log full length was dragged over the terrain) and transported to a log landing where logs were loaded into a truck bed.

Cable yarding - once the trees were felled manually, logs were fully suspended as they were transported uphill by a cable system that operated with a regular winch. No skid trails were constructed in this operation.

Animal yarding (Oxen) - at the felling sites, logs were cut in smaller lengths, loaded by hand in a small cart pulled by oxen, and transported down the hill to a log landing.

Control (undisturbed forest) - the second year, runoff plots were installed in an undisturbed forest, with Pinus oocarpa. The understory had different grasses, dominated by one species: Hyparhenia rufa. For the purpose of this study, cable and animal yarding systems were considered BMP treatments.

To detect soil conditions disparities among sites, soil samples from each horizon were taken from the soil profile at each harvest unit (Figueroa et al. 1983). Soil losses were measured in a calibrated drum and measurement commenced at all plots at the same time. The sediment collectors had a sediment trap to retain the coarser sediments. Measurements were performed daily or whenever a rainfall event occurred. Runoff volume, the amount of water in the metal collector, was recorded and a 1-liter stirred sample was taken to determine suspended sediment (fine particles) distribution. At the lab, sediment content from the samples was determined using the method described by Kunkle and Thames (1976) and Rawls et al. (1992). A recording rain gauge was installed at both watersheds.

\subsection{Rainfall pattern}

Rainfall amount, duration and intensity were determined for each storm over a 3 year period (19982000). Figure 3 shows the precipitation data between 1999 and 2000 for the town of Siguatepeque. Notice that precipitation values at each plot site may vary, duet to the spatial variability of rainfall. Annual precipitation regime has a monthly variation characterized by a bimodal rainfall pattern, where it has typically

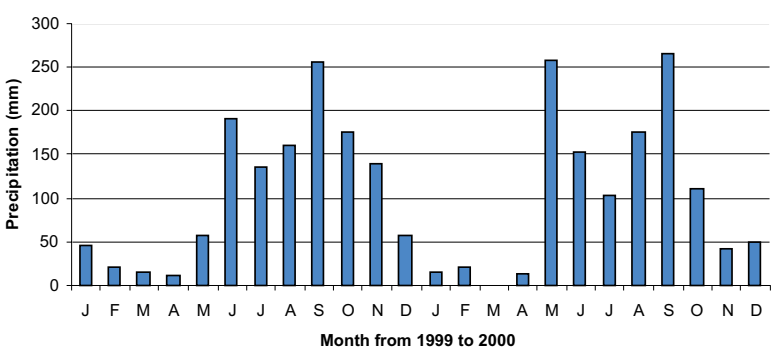

Figure 3 - Monthly rainfall from 1999 through 2000 at Siguatepeque, Honduras.

Figura 3 - Precipitação mensal de 1999 a 2000, em Siguatepeque, Honduras.

two peaks that divide the rainy season in two parts. The first part starts in late May or early June and ends in July or August. There is a short dry season of one or two months, then rain begins in August through October. September is the month with the highest precipitation, and these months are also the months of maximum flows. Essentially no significant runoff occurs May and July. Measurements were taken mainly during the second half of the rainy season because most erosion problems occur later as soils become saturated. Between the two year study period, around 3,200 daily samples of sediment, runoff and precipitation were recorded at the runoff plots of each treatment.

Rainfall intensities are also very high. Approximately, 95\% of the rainfall is considered "erosive rain" (storm that exceeds $25.6 \mathrm{~mm} / \mathrm{h}$ [Wishmeier and Smith 1978]). A 5-year study indicates that $50 \%$ of all rainfall events had a higher intensity than $20 \mathrm{~mm} / \mathrm{h}$ (Thurow and Smith 1998). Greater than half of Honduras might experience $300 \mathrm{~mm}$ of rain in 24 hours (Hargreaves 1992).

During October of 1998 extremely high rain events occurred due to hurricane Mitch. The erosion plots from this year were lost and replaced at the beginning of the next year.

\subsection{Analysis}

Sediment yield and runoff volume variables were analyzed using a Split Plot Design with the variable time (in months of rainfall) nested within explicit repeated measures (SAS 1999). This design allowed us to detect differences between treatments (yarding methods) throughout the rainy seasons of 1999 and 2000. Lower sediment production and runoff volume revealed the efficiency of one of the treatments. Comparisons of Means tests were performed to observe the differences 
between individual treatments against all others. Most data did not meet normality requirements and were log-transformed before the analyses. For the statistical analyses we used a significance level of $\alpha=0.05$. The statistical package of the R software was used for exploratory analyzes to find correlations and eliminate redundancy. A Classification and Regression Tree (CART) analysis was conducted, however the output provided very little meaningful data. The software Curve Expert 1.3 , which is a comprehensive curve-fitting system for Windows (http://www.ebicom.net/ dhyams/ cmain.htm) was utilized for fitting the models of daily erosion and runoff with daily precipitation for each treatment.The program MS Excel was used to manipulate the data and graphic production.

\section{RESULTS AND DISCUSSION}

\subsection{Sediment yield and runoff for Year 1}

Sediment yield reached its maximum value in September when the highest precipitation occurred (322 mm) (Figure 4) during the rainy season. The tractor-logged area reached an average sediment yield of 15,311 kg/ha (SD=14,708), while the cable-logged area yielded 1,490 kg/ha (SD=1,205). The lowest sediment yields were produced during the month of July, reaching $459 \mathrm{~kg} / \mathrm{ha}(\mathrm{SD}=411)$ for the tractor- and $99 \mathrm{~kg} / \mathrm{ha}(\mathrm{SD}=34)$ for the cable-yarding treatments. During the rainy season, precipitation was lowest in July at $77 \mathrm{~mm}$. Despite the large variation between replicates, differences were statistically significant between treatments $(\mathrm{P}=0.013)$.

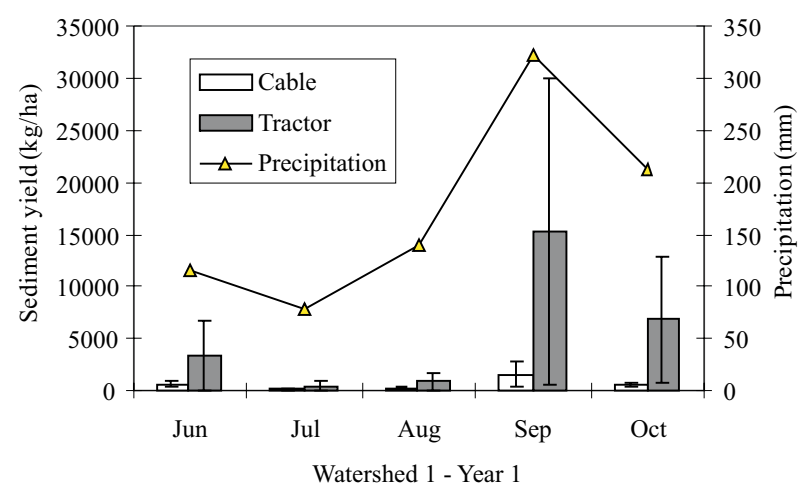

Figure 4 - Sediment yield from different yarding systems in Watershed 1-Year 1. The yarding methods are: cable yarding and tractor yarding.

Figura 4-Rendimento do sedimento dos sistemas diferentes do carregamento. Os métodos do carregamento são: carregamento do cabo e carregamento do trator.
The ANOVA results also showed significant differences between measurements among months $(\mathrm{P}<0.001)$ and among treatments (ANOVA; $\mathrm{P}=0.002)$. Sediment yield from tractor- and cable-yarding was different over all months of the rainy season in watershed 1; clearly indicating that tractor yarding produced more sediment than cable yarding. Sediment yield increased as the monthly precipitation increased showing a significant difference throughout all months $(\mathrm{P}<0.001)$. Sediment yield increased as the rainy season developed and then decreased towards the end of the rainy season to the original starting point.

Runoff volume followed the same pattern as sediment yield. The highest runoff occurred in September in the tractor-logged area (Average $=64.4$ $\mathrm{mm}$; $\mathrm{SD}=16.6$ ), while the cable-logged area produced significantly less runoff during the same time period (Average=39.8 mm; SD=6.7) (Figure 5). The month with the lowest runoff volume during the rainy season was July (Figure 3 and 5). Runoff volumes in the tractor-logged sites were significantly higher than in the cable-logged sites (ANOVA; $\mathrm{P}=0.030$ ). There was also a significant difference among months of the rainy season (ANOVA; $\mathrm{P}<0.0012$ ); however, there was no interaction between treatments (cable and tractor) over the months of the rainy season (ANOVA; $\mathrm{P}=0.112$ ).

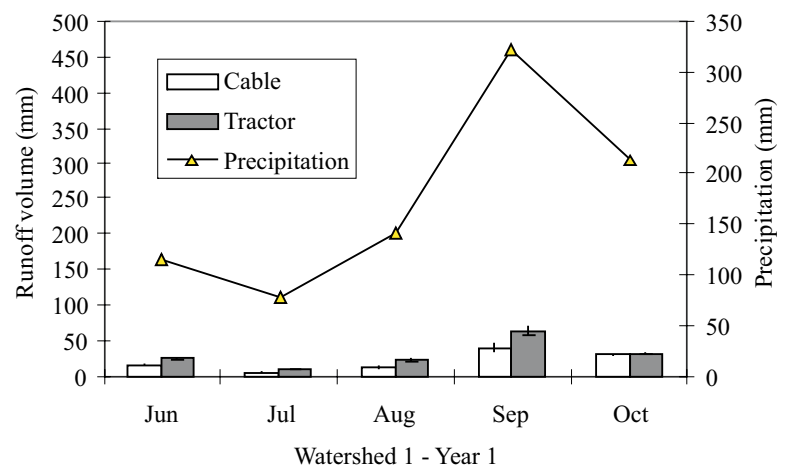

Figure 5 - Runoff volume from different yarding systems in Watershed 1-Year 1. The two different methods are: cable yarding and tractor yarding.

Figura 5 - Volume do escorrimento dos sistemas diferentes do carregamento. Os dois métodos diferentes são: carregamento do cabo e carregamento do trator.

Revista Árvore, Viçosa-MG, v.34, n.4, p.577-586, 2010 
There were also differences in runoff between the early rainy season and the late rainy season. A test of Differences of Least Squares showed that there were significant differences in runoff between July and September, July and October, August and September, and September and October $(\mathrm{P}<0.001)$. The other combinations did not show significant differences (July and June, and July and August).

Cable systems (high-lead and skyline) reduce soil removal and erosion because logs are either partially or fully suspended above ground thus creating less soil disturbance. Smith (after Seyedbagheri 1996) found that skyline systems had an average of $10 \%$ disturbed area. Similar results were found by Cromack et al. (1978), where high-lead systems produced less than half of the erosion produced by a typical skidder tractor-yarding operation. Tractor yarding displaces more soil than the other yarding systems, thus the use of tractors should be minimized, especially when tractor use is unavoidable.

\subsection{Sediment yield and runoff for year 2}

Tractor yarding produced the largest amount of sediment, followed by cable yarding. The tractor-logged treatment yielded nearly $1,846 \mathrm{~kg} / \mathrm{ha}(\mathrm{SD}=1,525)$ of sediment, while the cable-logged area yielded $320 \mathrm{~kg} / \mathrm{ha}$ $(\mathrm{SD}=184.2)$ (Figure 6). Sediment yield at the control plots was significantly higher than the animal-yarding

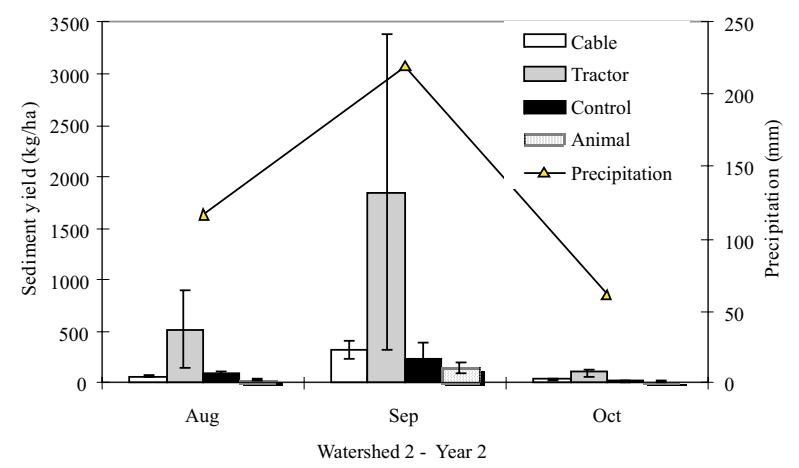

Figure 6 - Sediment yield from different yarding systems in Watershed 2-Year 2. The three different methods are: cable yarding, tractor yarding, and animal yarding. Erosion in a natural, undisturbed forest (control) is also compared with the three treatments.

Figura 6 - Rendimento do sedimento dos sistemas diferentes de carregamento. Os três métodos diferentes são: cabo, o carregamento, o carregamento do trator e o carregamento animal. A erosão em uma floresta natural, imperturbada (controle), é comparada igualmente com a dos três tratamentos. plots $(\mathrm{P}<0.0001)$. Animal yarding reached only $146.4 \mathrm{~kg} /$ ha of sediment yield ( $\mathrm{SD}=55.7$ ), while the control plot (undisturbed forest) reached $245 \mathrm{~kg} / \mathrm{ha}$ (SD=153). Tractor yarding produced more sediments and sediment yield increased as precipitation increased. Sediment yield reached its maximum value in September, the month with the highest precipitation (220 mm).

The lowest sediment yield for all treatments was during the month of October. Sediment yield values were significantly different between all months $(\mathrm{P}<0.001)$, and there were significant differences in all the interactions of treatments versus time during the three months of study $(\mathrm{P}<0.0001)$. Statistical analysis showed significant differences among treatments (ANOVA; $\mathrm{P}<0.0001$ ) and for interaction between months and types of yarding (treatments) (ANOVA; $\mathrm{P}=0.0004)$.

Runoff volume followed a pattern similar to that of sediment yield in each of the treatments. Runoff peak occurred in September, the month of highest precipitation. BMP treatments produced significantly lower runoff volumes in all cases. The tractor-logged area had the highest runoff volume, reaching its peak in September (Average $=16.5 \mathrm{~mm} ; \mathrm{SD}=9.9$ ). The cable-logged site produced the next lowest runoff volume (Average $=8.2 \mathrm{~mm}$; $\mathrm{SD}=0.8$ ) followed by animal yarding (Average=7.1 mm; $\mathrm{SD}=1.4$ ). The undisturbed forest produced an average runoff volume of $8.4 \mathrm{~mm}(\mathrm{SD}=2.2)$. The lowest runoff volume occurred in October $(<3 \mathrm{~mm})$ (Figure 7$)$.

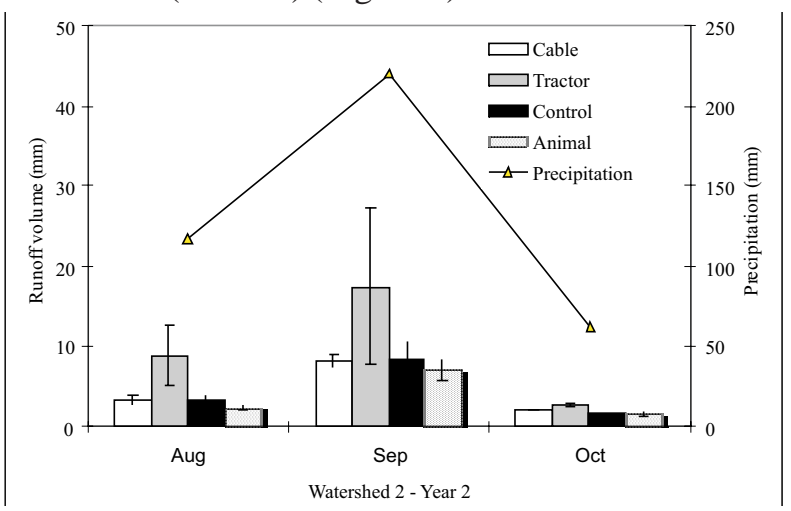

Figure 7 - Runoff volume from different yarding systems in Watershed 2- Year 2. The three different methods are: cable yarding, tractor yarding, and animal yarding. Erosion in a natural, undisturbed forest (control) is also compared with the three treatments.

Figura 7 - Volume do escorrimento dos sistemas diferentes do carregamento. Os três métodos diferentes são: cabo de carregamento, o carregamento do trator e o carregamento animal. A erosão em uma floresta natural, imperturbada (controle), é comparada igualmente com a dos três tratamentos. 
Statistical analysis showed a significant difference in runoff volume among the types of yarding systems (ANOVA; $\mathrm{P}<0.0001$ ). It also showed a significant difference among months of the rainy season (ANOVA; $\mathrm{P}<0.0001$ ), and there was an interaction between treatment and months (ANOVA; $\mathrm{P}=0.007$; Fig. 7). There were also significant differences in runoff between August and September, August and October, and September and October $(\mathrm{P}<0.001)$.

Alternative yarding methods significantly decrease the amount of sediment and runoff from timber harvest sites (Satterlund and Adams 1992, Seyedbagheri 1996). When using alternative methods such as yarding with cable or animals, sediment yield can be almost as low as the natural erosion rate in an undisturbed forest. These results are very consistent with previous findings in North America, where sediment production I yarding systems follow this order - from highest to lowest erosion-: tractor, cable and animal yarding systems.

\subsection{Overall comparison of runoff and sediment yield among treatments}

Comparing the results in both watersheds, we observed that runoff volume was also higher at the tractor yarding treatment, followed by cable yarding and animal yarding which had a runoff volume similar to an undisturbed forest (Figure 8). The runoff volume pattern resulted very consistent with the pattern for sediment yield. The control plots established in undisturbed forest areas reveal that the cable and animal yarding produced minimal effects on the ground, in terms of disturbance, and their runoff values are very similar to areas of unlogged conditions, in terms of runoff volume produced. It is also important to mention that the runoff pattern does not show an abrupt difference among treatments. These experiments showed that even when the runoff is high in an undisturbed forest, the sediment content is much lower than other disturbed areas. This demonstrated the high capacity of these watersheds to produce runoff, but retain sediment under natural conditions (Hudson et al. 1983).

The overall erosion rate shows a more dramatic effect when compare among different yarding treatments (Fig. 9). These results are very consistent with other studies in Central America and differ little from the results found in the Western United States (Megahan 1980, Hudson et al. 1983, Seyedbagheri 1996). In general, the erosion rate in tractor-logged areas was six to ten

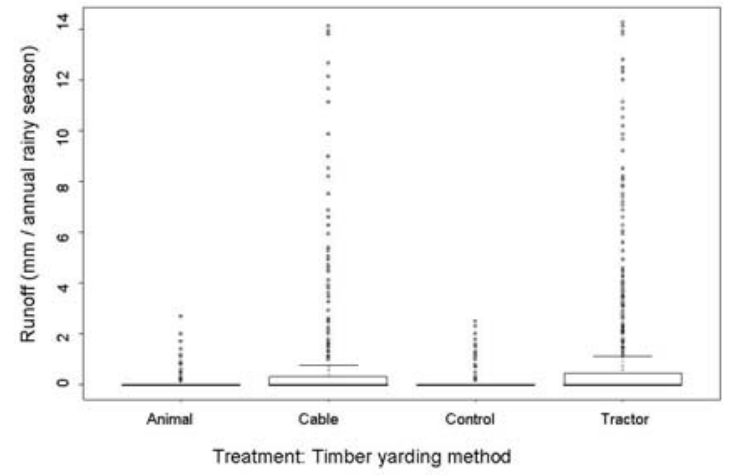

Figure 8 - Runoff volume per treatments per rainfall event for the two watersheds in the two-year study period.

Figura 8 - Volume do escorrimento por tratamentos e por evento da precipitação nos dois marcos decisivos no período bienal do estudo.

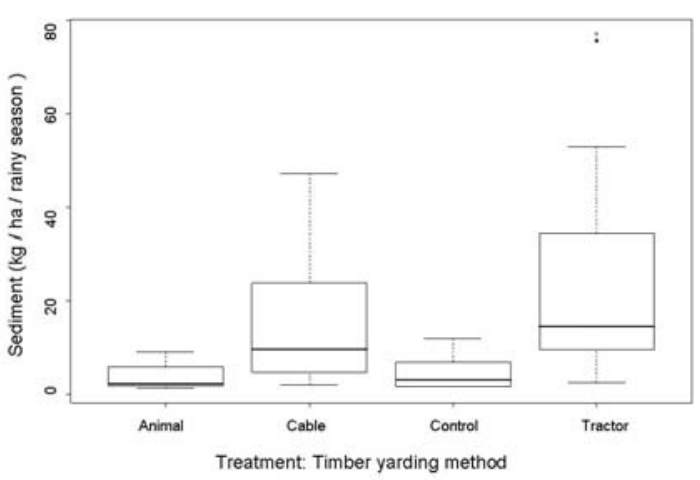

Figure 9 - Sediment production per treatments per rainfall event for the two watersheds in the two-year study period.

Figura 9 - Produção do sedimento por tratamentos e por evento da precipitação nos dois marcos decisivos no período bienal do estudo.

times higher than the erosion produced by cable yarding (Fig 9). These results are also consistent with other animal yarding studies which suggest that animal skidding also disturbs less soil than tractor skidding, resulting in little site disturbance (Satterlund and Adams1992; Studier et al. 1984; FAO 1989). Numerous research studies and published papers have documented high erosion rates resulting from tractor yarding (US Forest Service 2006; Lynch and Corbett 2007).

\subsection{Correlations}

Table 1 describes the correlation models obtained from correlating daily precipitation against runoff and sediment production for all types of yarding systems.

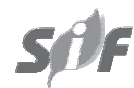

Revista Árvore, Viçosa-MG, v.34, n.4, p.577-586, 2010 
Table 1 - Best fit models by correlating daily precipitation against runoff and sediment production for all types of yarding systems.

Tabela 1 - O melhor ajuste de modelo da precipitação diária de correlacionamento contra à produção do escorrimento e do sedimento para todos os tipos de sistemas do carregamento.

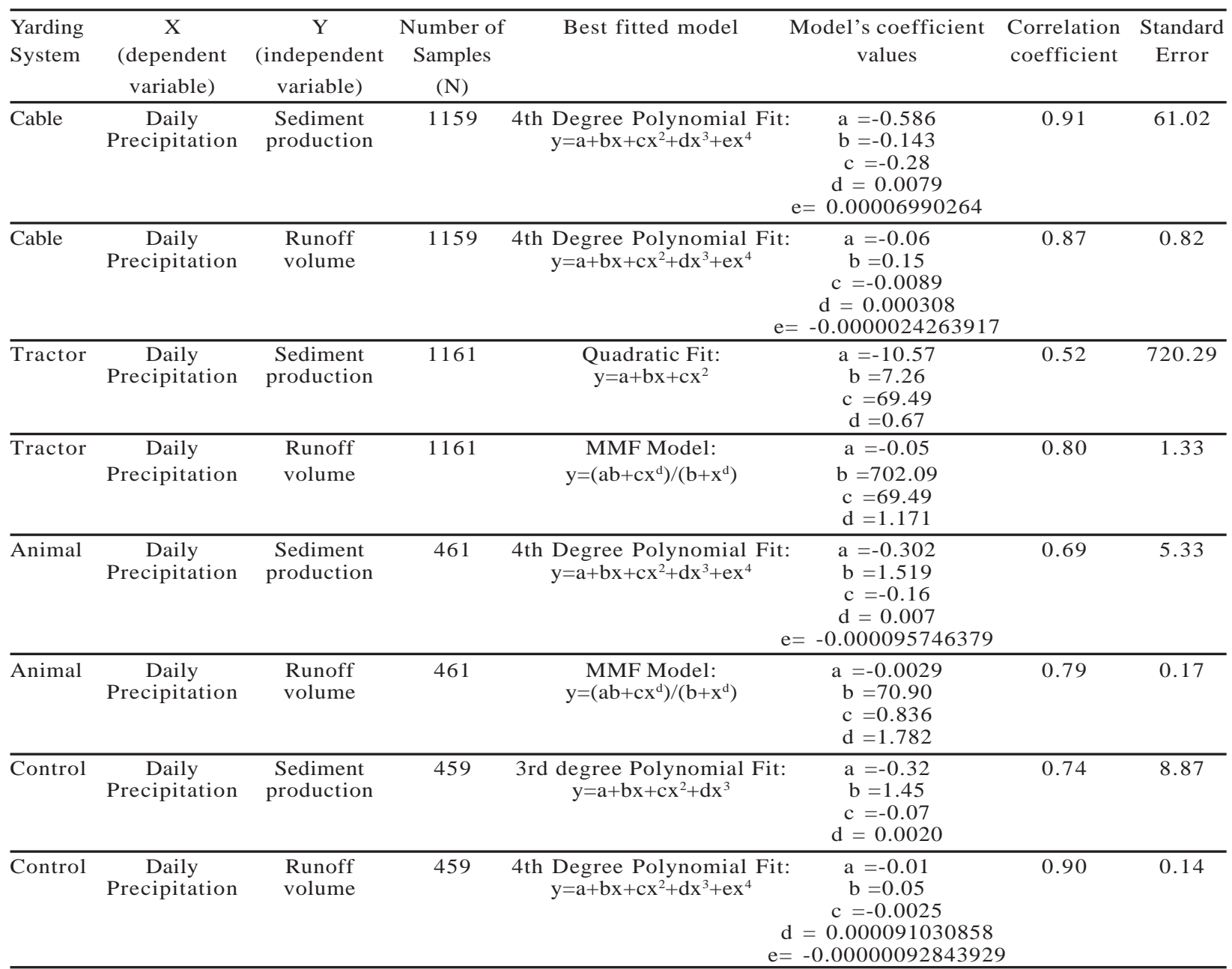

The software Curve Expert 1.3 (http:// www.ebicom.net/ dhyams/cmain.htm) was able to select the best fit model over a wide variety of models ranging from linear, polynomial, exponential, growth, logarithmic, and sigmoidal models. Table 1 shows the best selected models for all yarding systems. All of the models resulted in polynomial fits (Quadratic, $3^{\text {rd }}$ and $4^{\text {th }}$ degree equations), except for Cable (precipitation and runoff) and Animal (precipitation and runoff) the best fit resulted for the Morgan Mercer Flodin model (MMF model), which is a flexible sigmoid used to describe growth processes or other processes with non linear structure (Piegorsch and Bailer 2005). Higher correlation coefficients were for Cable yarding for both correlations: precipitation and sediment production and precipitation and runoff volume (0.91 and 0.87, respectively). Control, for precipitation and runoff volume also resulted in a higher correlation coefficient (0.90). Lowest correlation resulted for tractor yarding for daily precipitation and sediment production (0.52) and also with a high standard error (720.29).

Revista Árvore, Viçosa-MG, v.34, n.4, p.577-586, 2010 


\section{CONCLUSIONS}

The results of this study showed that soil losses from different yarding methods were in this order - from the highest to the lowest-: . Tractors (traditional yarding), cable timber yarding using skyline cable (BMPs), animal yarding (oxen, BMPs), and undisturbed forest (control, no-yarding). We can also conclude that runoff volume shows, a less pronounced pattern, but a similar tendency. We observed that runoff volume was also higher at the tractor yarding treatment, followed by cable yarding and animal yarding which had a runoff volume similar to an undisturbed forest. The results of these timber yarding experiments also showed that both the cable and the animal yarding systems were low-impact. In Honduras, where the erosion hazard is high, animal yarding systems may be an appropriate alternative harvest method.

September, the month with the highest precipitation value, was the month of the highest sediment yield. Sediment yield increased as the rainy season developed and then decreased towards the end of the rainy season to the original starting point. The temporal variation of sediment production and runoff volume varied according to the annual rainfall pattern. Sediment yield increased as the monthly precipitation increased showing a significant difference throughout all months of the rainy seasons.

\section{ACKNOWLEDGMENTS}

We would like to thank to the sponsor of this research project: the U.S. Department of Agriculture through the Foreign Agricultural Service and the International Cooperation Scientific Exchange Program. The US Forest Service- Fish and Ecology Unit at Utah State University provided the logistical support for this study.

\section{REFERENCES}

ARCOVA', F. C. S.; CICCO, V.; ROCHA, P. A. B. R. Net precipitation and interception by Mata Atlântica in an experimental catchment in Cunha São Paulo, Brazil. Revista Árvore, v.27, n.2, p.257-262, 2003.

CLAYTON, R. A. Overview of best management practices effectiveness and the center for watershed protection's national pollutant removal performance database. In: proceedings of the Water Environment Federation. National TDML Science policy. Alexandria:Water Environment Federation Publisher, 2002. 136-147p.
COHDEFOR. Plan de accion forestal de largo plazo 1996-2015. Tegucigalpa: Unidad de Planificacion Institucional/AFECOHDEFOR, 2005.127p.

CROMACK, K.; SWANSON, F. J.; GRIER, C. C. A comparison of harvesting methods and their impact on soils and environment in the Pacific Northwest. From forest soil and land use. In: NORTH AMERICA FOREST SOILS CONFERENCE, 5., 1978, Fort Collins. Proceedings... Fort Collins: Colorado State University, 1979.

\section{CURVE EXPERT version 1.3. A Curve-fitting System for Windows (http:// www.ebicom.net/ dhyams/cmain.htm) 2008.}

FOOD AND AGRICULTURE ORGANIZATION OF UNITED NATIONS - FAO. Watershed management field manual; Road design and construction in sensitive watersheds. Rome: FAO, 1989. 405p.

FIGUEROA, B.; MARTINEZ, L.; PEREZ, R. Instructivo para el establecimiento de lotes de escurrimiento. México: SARH, 1983.55p.

HARGREAVES, G. Hydrometereologic data for Honduran water resources development. Logan: USU, Dep. of Biological and Irrigation Engineering, 1992. 77p.

HUDSON, J. et al. Prescribed burning of Pinus oocarpa in Honduras: Effects on surface runoff and sediment loss. Forest Ecology and Management, v.5, p.269-281, 1983.

ICE, G. G.; NEARY, D. G.; ADAMS, P. W. Effects of wildfires on soils and watershed processes. Journal of Forestry, v.102, n.6, p.16-20, 2004.

KIRCHNER, J. W. et al. Mountain erosion over $10 \mathrm{yr}, 10 \mathrm{k} . \mathrm{y}$., and $10 \mathrm{~m} . \mathrm{y}$. time scales. Geology, v.29, n.7, p.591-594, 2001

KUNKLE, S. H.; THAMES, J. L. Hydrological techniques for upstream conservation. Rome: Food and Agricultural Organization, 1976. 52p.

LYNCH, J. A.; CORBETTT, E. S. Evaluation of best management practices for controllingp non point pollution from silvicultural operations.

Journal of the American Water Resources Association. On-line version,. v.26, n.1, p. 41-52, 2007.

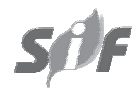

Revista Árvore, Viçosa-MG, v.34, n.4, p.577-586, 2010 
MEGAHAN, W. F. Nonpoint source pollution from forestry activities in the western United States: results of recent research and research needs. In: INTERMOUNTAIN FOREST AND RANGE EXPERIMENTAL STATION. USDA Forest Service, 1980, Boise. In: Proceedings of conference on U.S. forestry and water quality: What Course in the 80's? Richmond: Water Pollution Control Federation, 1980. p.35-59.

OLIVEIRA JUNIOR, J. C.; DIAS, H. C. T. Net precipitation in a forest fragment of Mata Atlantica. Revista Árvore, v.29, n.1, p.9-15, 2005.

PIEGORSCH, W. W.; BAILER, J. Analyzing environmental data. New York: John Wiley \& Sons, 2005. 496p.

RAWLS, W. J. et al. Soil water movement and infiltration. In: MAIDMENT, D. R.

Handbook of hydrology. New York: McGraw Hill, 1992. 505p.

RIBEIRO, S. C. et al. Estimation of erosion reduction carried out by agrosilvopasture system and its economic contribution. Revista Árvore, v.31, n.2, p.285-293, 2007.

RIVERA, S. et al. 2009. Soil and economic loss evaluation at small hillside farms located in the central mountains of Honduras, Central America. Unpublished. Accepted for publication at the Journal of Sustainable Forestry on December 8, 2008.

R SOFTWARE. The R Project for Statistical Computing.2008. http://www.rproject.org/

SAS Institute. Statistical Analysis System (SAS); procedures guide, release 6.03 edition. Cary: 1999.

SATTERLUND, D. R.; ADAMS, P. W. Wildland watershed management. 2.ed. New York: The Ronald Press Company, 1992. 436p.
SEYEDBAGHERI, K. A. Idaho forestry best management practices: compilation of research on their effectiveness U.S. For. Serv. Gen. Tech. Rep. INT-GTR 339. Boise: US Forest Service, Intermountain Research Station, 1996. 90p.

SIMMONS, C.; CASTELLANOS, V. Informe al Gobierno de Honduras sobre los suelos de Honduras. Roma, Programa de las Naciones Unidas para el Desarrollo. Organizacion de las Naciones Unidas para la Agricultura y la Alimentación, 1969. 88p.

STUDIER, D. et al. Section on logging. In: WENGER, K. F. Forestry handbook. 2.ed. New York: Society of American Foresters, 1984. 1335p.

THUROW, T. L.; SMITH, J. E. Assessment of soil and water conservation methods applied to the cultivated steeplands of Southern Honduras. College Station: US Agency for International Development. Soil Management Collaborative research Support Program. Texas A\&M University, 1998. 39p. (Technical Bulletin, 98-2)

US FOREST SERVICE. FSH 2509.22 Soil and water conservation handbook. Water quality management for national forest system lands in Alaska. Washington: USDA Forest Service, 2006.117p.

US FOREST SERVICE. Soil and water conservation handbook, FSH 2509.22. Juneau, Alaska. Washington: USDA Forest Service, 1993. 545p.

U.S. ENVIRONMENT PROTECTION AGENCYUSDA FOREST SERVICE. An approach to water resources evaluation of non point silvicultural sources (a procedural handbook). Springfield: EPA-USDA Forest Service, 1980. 367p.

WISChMEIER, W. H.; SMITH, D. D. Predicting rainfall losses: A guide to conservation planning. Washington: USDA/Science and Education Administration, 1978. 210p. 